\title{
Double-blind comparison of granisetron, promethazine, or a combination of both for the prevention of postoperative nausea and vomiting in females undergoing outpatient laparoscopies Comparaison en double aveugle du granisétron, de la prométhazine ou d'un traitement combiné dans la prévention des nausées et vomissements postopératoires chez les patientes subissant une laparoscopie en ambulatoire
}

\author{
Tong J. Gan, MB $\cdot$ Keith A. Candiotti, MD $\cdot$ Stephen M. Klein, MD • \\ Yiliam Rodriguez, MD - Karen C. Nielsen, MD - William D. White, MPH · \\ Ashraf S. Habib, MB
}

Received: 11 April 2009/Accepted: 11 August 2009/Published online: 3 September 2009

(C) Canadian Anesthesiologists' Society 2009

\begin{abstract}
Purpose Postoperative nausea and vomiting (PONV) and postdischarge nausea and vomiting (PDNV) are common problems after surgery. Prophylactic combination antiemetic therapy is recommended for patients at high risk for developing PONV and PDNV. Granisetron, a serotonin antagonist, is an effective antiemetic that is devoid of sedative side effect. Although promethazine is effective, commonly used doses are associated with sedation. This study investigates the combination of low doses of granisetron and promethazine for the prevention of PONV.

Methods Women undergoing ambulatory gynecological laparoscopy were enrolled. A standard general anesthetic regimen was prescribed. Fifteen minutes before the expected end of surgery, the patients were randomly assigned to receive granisetron $0.1 \mathrm{mg} \mathrm{iv}$, promethazine $6.25 \mathrm{mg}$ iv, or a combination of the two drugs. Prophylaxis with oral promethazine $12.5 \mathrm{mg}$, granisetron $1 \mathrm{mg}$, or both was started in the respective groups $12 \mathrm{hr}$ after the end of surgery and continued every $12 \mathrm{hr}$ until postoperative day
\end{abstract}

T. J. Gan, MB $(\bowtie) \cdot$ S. M. Klein, MD - K. C. Nielsen, MD . W. D. White, MPH · A. S. Habib, MB

Department of Anesthesiology, Duke University Medical Center, Durham, NC 27710, USA

e-mail: tjgan@duke.edu; gan00001@mc.duke.edu

K. A. Candiotti, MD · Y. Rodriguez, MD

Department of Anesthesiology, Perioperative Medicine and Pain

Management, University of Miami, Miami, FL, USA
3 (a total of five oral doses). The following outcomes were recorded: total response rate (defined as no vomiting, no more than mild nausea, and no use of rescue antiemetic); incidence of nausea, vomiting, and use of rescue antiemetics; severity of nausea; patient activity level; and patient satisfaction with PONV management.

Results Patients in the combination group had a higher total response rate at 6, 24, 48, and $72 \mathrm{hr}$ after surgery compared with those who received promethazine alone (at $24 \mathrm{hr}$, Combination 69.6\%, Promethazine 36.2\%, Granisetron 53.3\%; $P=0.0079)$. The maximum nausea scores were also lower in the combination group at 6, 24, 48 , and $72 \mathrm{hr}$ (Combination $1.7 \pm 2.2$, Promethazine $4.0 \pm 3.6$, Granisetron $3.1 \pm 3.2$ at $24 \mathrm{hr} ; \quad P<0.05$ ). There was no difference in the sedation scores, incidence of drowsiness, patient activity level, and satisfaction with PONV management.

Conclusions Low-dose granisetron and promethazine combination was more effective in reducing PONV and $P D N V$ than promethazine monotherapy. The combination also reduced the severity of nausea.

\section{Résumé}

Objectif Les nausées et vomissements postopératoires (NVPO) et les nausées et vomissements après le congé sont des problèmes courants à la suite d'une chirurgie. Un traitement antiémétique combiné prophylactique est recommandé chez les patients présentant un risque elevé de NVPO et de nausées et vomissements après le congé. Le 
granisétron, un antagoniste de la sérotonine, est un antiémétique efficace qui n'a pas d'effet secondaire de sédation. Bien que la prométhazine soit efficace, les dosages communément utilisés sont associés à une sédation. Cette étude examine un traitement combiné de faibles doses de granisétron et de prométhazine pour la prévention des NVPO.

Méthode Des femmes subissant une laparoscopie gynécologique ambulatoire ont participé à l'étude. Un régime d'anesthésie générale standard a été prescrit. Quinze minutes avant la fin prévue de la chirurgie, les patientes ont été randomisées à recevoir soit $0,1 \mathrm{mg}$ de granisétron $i v$, soit $6,25 \mathrm{mg}$ de prométhazine $i v$, ou un traitement combiné des deux médicaments. Les différentes prophylaxies, soit $12,5 \mathrm{mg}$ de prométhazine orale, $1 \mathrm{mg}$ de granisétron ou le traitement combiné, ont été initiées dans les groupes respectifs $12 \mathrm{hr}$ après la fin de la chirurgie et continuées chaque $12 \mathrm{hr}$ jusqu'au jour postopératoire 3 (total de cinq doses orales). Les résultats suivants ont été enregistrés: le taux de réponse total (défini en tant qu'absence de vomissement, nausées légères seulement, et la non-utilisation d'antiémétiques de secours); l'incidence de nausées, de vomissements, et l'utilisation d'antiémétiques de secours; la gravité des nausées; le niveau d'activité des patientes; et la satisfaction des patientes concernant la prise en charge des NVPO.

Résultats Les patientes dans le groupe de traitement combiné ont eu un taux de réponse total plus élevé $6,24,48$ et $72 \mathrm{hr}$ après la chirurgie comparativement à celles recevant de la prométhazine seulement (à $24 \mathrm{hr}$, groupe traitement combiné 69,6\%, prométhazine $36,2 \%$, granisétron 53,3\%; $P=0,0079$ ). Les scores maximaux de nausées étaient également plus bas dans le groupe traitement combiné à 6, 24, 48 et $72 \mathrm{hr}$ (groupe traitement combiné $1,7 \pm 2,2$, prométhazine 4,0 $\pm 3,6$, granisétron $3,1 \pm 3,2$ à $24 \mathrm{hr} ; \mathrm{P}<0,05)$. Il n'y a pas eu de différence dans les scores de sédation, l'incidence de somnolence, le niveau d'activité des patientes et la satisfaction concernant la prise en charge des NVPO.

Conclusion Un traitement combiné de granisétron et de prométhazine à faible dose était plus efficace pour réduire les NVPO et les nausées et vomissements après le congé qu'une monothérapie de prométhazine. Le traitement combiné a également réduit la gravité des nausées.

Despite significant advances in the management of postoperative nausea and vomiting (PONV) and postdischarge nausea and vomiting (PDNV), they continue to pose a significant problem with a reported incidence from $35 \%$ to more than $70 \% .^{1-3}$ Recent consensus panel guidelines recommended the prophylactic use of combination antiemetic therapy for patients who are at high risk for developing PONV. ${ }^{4}$
The $5-\mathrm{HT}_{3}$ receptor antagonists are popular in the ambulatory setting because of their lack of sedative side effects. Granisetron is a $5-\mathrm{HT}_{3}$ receptor antagonist that is proven to be effective for the prophylaxis and treatment of PONV. It has been used for the management of PONV in doses of $0.35-3 \mathrm{mg} .{ }^{5}$ Although most studies have demonstrated efficacy at $1 \mathrm{mg}$ for prophylaxis, a recent pilot study suggested it might be efficacious at lower doses $(0.1 \mathrm{mg}){ }^{6}$ The use of this lower dose for the prevention of PONV and PDNV has not been studied previously.

Promethazine, a phenothiazine, is one of the older generation antiemetics that has not been well studied. Earlier reports suggest that its use was associated with delayed recovery from anesthesia due to its sedative properties. ${ }^{7}$ Two previous studies, however, did not find a difference in the length of postanesthesia care unit (PACU) stay between patients who received promethazine $12.5 \mathrm{mg}$ and those who received ondansetron. ${ }^{8,9}$ Although lower doses of promethazine have been advocated for the treatment of PONV with a lower risk of sedation, ${ }^{8}$ this dose has not been formally studied for prophylaxis.

Most antiemetics have relatively short half-lives, about 6-8 hr. ${ }^{7}$ Hence, redosing of antiemetics may be important to prolong their antiemetic effects after discharge from the day surgery unit. A combination of low doses of granisetron and promethazine has not been reported. Moreover, the repeat doses of these antiemetics beyond discharge have not been formally assessed. Therefore, the objective of this study was to compare the antiemetic efficacy of these two antiemetics, by themselves or in combination, for the prevention of PONV when administered for $72 \mathrm{hr}$ in the immediate postoperative period and beyond discharge.

We tested the following hypothesis: granisetron and promethazine combination therapy is superior to individual antiemetics when used alone for the prevention of PONV in women undergoing outpatient gynecological laparoscopy under general anesthesia. The primary outcome was the incidence of total response (defined as no vomiting, no more than mild nausea, and no use of rescue medication) at $24 \mathrm{hr}$. The secondary outcomes recorded until $72 \mathrm{hr}$ post surgery included the incidence and severity of nausea, the incidence of vomiting and use of rescue antiemetics, sedation, duration of recovery room stay, functional recovery, and patient satisfaction.

\section{Methods}

This was a prospective randomized controlled clinical trial. One hundred thirty-eight subjects were enrolled at Duke University Health System (77 subjects) and at the Jackson Memorial Hospital, University of Miami, Florida (61 subjects). Institutional Review Board approval and 
patient informed consent were obtained at both institutions. Adult female patients with American Society of Anesthesiologists (ASA) physical status I, II, and III, who were scheduled for elective outpatient gynecological laparoscopy requiring general anesthesia of at least $30 \mathrm{~min}$ duration were eligible. Patients who had a hypersensitivity reaction or known idiosyncrasy to any of the study medications were excluded. The following exclusion criteria were also used: pregnancy; any medical illnesses which, in the view of the investigators, would interfere with the study outcome; a history of substance abuse or psychiatric disease; medications with known antiemetic properties taken preoperatively or $48 \mathrm{hr}$ before the scheduled surgical procedure; or symptoms of nausea or vomiting before the first dose of study medications was administered.

The study plan called for patients to be randomized into three treatment groups of 45 patients each. Randomization was achieved using computer-generated codes, and the group assignment was prepared in sealed opaque envelopes.

\section{Group A: granisetron}

Granisetron $0.1 \mathrm{mg}$ and a matching saline placebo were administered intravenously $15 \mathrm{~min}$ before the expected end of surgery. Prophylaxis with oral granisetron $1 \mathrm{mg}$ and an identical placebo tablet were started $12 \mathrm{hr}$ after the end of surgery and were continued every $12 \mathrm{hr}$ until postoperative day 3 (five oral doses).

\section{Group B: promethazine}

Promethazine $6.25 \mathrm{mg}$ and a matching saline placebo were administered intravenously $15 \mathrm{~min}$ before the expected end of surgery. Prophylaxis with oral promethazine $12.5 \mathrm{mg}$ and an identical placebo tablet were started $12 \mathrm{hr}$ after the end of surgery and were continued every $12 \mathrm{hr}$ until postoperative day 3 (five oral doses).

Group C: granisetron and promethazine

Granisetron $0.1 \mathrm{mg}$ and promethazine $6.25 \mathrm{mg}$ were administered intravenously $15 \mathrm{~min}$ before the expected end of surgery. Prophylaxis with oral promethazine $12.5 \mathrm{mg}$ and granisetron $1 \mathrm{mg}$ were started $12 \mathrm{hr}$ after the end of surgery and continued every $12 \mathrm{hr}$ until postoperative day 3 (five oral doses).

The intravenous and oral study medications were prepared by the hospital investigational drug service in syringes and gel capsules that looked identical. All intravenous study medications were diluted to $5 \mathrm{~mL}$ with saline. All patients received a standard anesthetic regimen for induction that included premedication with midazolam 1-2 mg, fentanyl $50 \mu \mathrm{g}$, and propofol $1-2 \mathrm{mg} \cdot \mathrm{kg}^{-1}$. A neuromuscular blocking drug of choice was used to facilitate tracheal intubation. Anesthesia was maintained with sevoflurane 1-3\%, oxygen $33-50 \%$ in air, and fentanyl $\leq 3 \mu \mathrm{g} \cdot \mathrm{kg}^{-1} \cdot \mathrm{hr}^{-1}$. A reversal of neuromuscular blockade was used consisting of neostigmine $0.04 \mathrm{mg} \cdot \mathrm{kg}^{-1}$ and glycopyrrolate 0.01 $\mathrm{mg} \cdot \mathrm{kg}^{-1}$. To ensure adequate hydration, $500 \mathrm{~mL}$ of lactated Ringer's solution was infused prior to induction of anesthesia and maintained at $4 \mathrm{~mL} \cdot \mathrm{kg}^{-1} \cdot \mathrm{hr}^{-1}$ throughout the surgery. All patients were monitored with standard ASA recommended monitors, including a train-of-four monitor, and their temperatures were maintained above $35.5^{\circ} \mathrm{C}$. The patients were transferred to the PACU following tracheal extubation.

\section{Outcomes measures}

Data were collected by research personnel who were blinded to the randomization and not involved with the clinical care of the patients. Incidence and severity of nausea; incidence of vomiting, retching, and rescue antiemetic use; pain and sedation scores ${ }^{10}$; and postoperative analgesia consumption (fentanyl 15-25 $\mu \mathrm{g}$ for severe pain) were recorded at $0,30,60 \mathrm{~min}$ and every half hour thereafter until discharge from the PACU. Also recorded were the duration of anesthesia (induction to extubation) and surgery (surgical incision to last stitch) and the time to achieve readiness for discharge from PACU using the modified Aldrete criteria ${ }^{11}$ (when patients were fully awake and oriented with stable vital signs and minimal pain $[<3$ on a $0-10$ scale], able to ambulate, and not experiencing side effects).

Patients were given a diary to record the incidence and severity of nausea and the incidence of vomiting/retching every $12 \mathrm{hr}$ following discharge. The patients also recorded when they could tolerate fluids and solid food, their quality of sleep, and when they were able to perform normal daily activity. At 24, 48, and $72 \mathrm{hr}$ following surgery, the patients were contacted by telephone to collect data from the questionnaire and to assess their satisfaction with the antiemetic management using a 0 (very dissatisfied) to 10 (very satisfied) scale.

Subjective experience with nausea and pain at rest was scored using an 11-point linear verbal rating scale (VRS) from 0 to 10 , with " 0 " representing no nausea or pain and " 10 " representing nausea or pain "as bad as it can possibly be." Vomiting and retching were defined as productive and unproductive expulsion of gastric content, respectively. Total response was defined as no vomiting/retching, no more than mild ( $<4$ on a $0-10$ scale) nausea, and no use of rescue antiemetic. Ondansetron $4 \mathrm{mg} i v$ was used as a rescue antiemetic and was administered when patients had a nausea score $>5$ for $15 \mathrm{~min}$ or longer, when they experienced two emetic or retching episodes within 
15 min, or at the patient's request. The choice of a subsequent rescue antiemetic, when needed, was left to the discretion of the anesthesiologist. Pain was treated with doses of fentanyl 15-25 $\mu \mathrm{g} i v$, as required, to keep the VRS score $\leq 3$ of 10 .

\section{Statistical considerations}

The primary endpoint in this trial was defined a priori as total response up to $24 \mathrm{hr}$ after surgery (yes/no). This and other categorical endpoints were compared among groups by exact Pearson's chi square tests, and continuous endpoints such as nausea or sedation VRS scores were compared by nonparametric Kruskal-Wallis tests. Where a three-group treatment test was significant, post-hoc pairwise group comparisons were made with Chi square or Rank-Sum tests. All post-hoc group comparisons were adjusted for the three multiple comparisons. All responses assessed at multiple times were adjusted for the five time points tested as well as for any post-hoc group comparisons. All $P$ values reported are adjusted. Adjustments were made using the stepwise-permutation method by Westfall et al. ${ }^{12}$ with 100,000 permutations. Significance was set for a familywise error rate alpha $=0.05$. All analyses were performed with SAS ${ }^{\circledR}$ statistical software version 9.1 (SAS Institute Inc, Cary, NC, USA).

Based on data from a previous study, we estimated a complete response rate of $80-84 \%$ for the combination group compared with $50 \%$ for the single agent group. ${ }^{6}$ With Chi-squared tests at an overall alpha $=0.05,45$ patients per group would provide $80 \%$ power to detect a $30 \%$ improvement among three groups and a $32 \%$ improvement in the combination group compared with each single agent group, after adjusting for three post-hoc pairwise comparisons between groups.

\section{Results}

A total of 138 patients completed the study. Figure 1 illustrates patient disposition. There were no differences in patient demographics between the groups (Table 1).

The primary endpoint, cumulative total response rate at $24 \mathrm{hr}$ after surgery, was significantly higher in the combination group than in the promethazine group (combination versus granisetron versus promethazine group, $70 \%$ versus $53 \%$ versus $36 \%$, respectively; $P=0.0055$ overall; $P=$ 0.0079 for combination versus promethazine; $P=0.29$ for combination versus granisetron; $P=0.29$ for promethazine versus granisetron). The combination group was superior to the promethazine group at $6,24,48$, and $72 \mathrm{hr}$ after surgery (Fig. 2). The granisetron group was consistently intermediate, i.e., not significantly different from either group. From 6 to $72 \mathrm{hr}$ after surgery, the maximum nausea scores were also significantly lower in the combination group than in the promethazine group. When compared with the granisetron group, the maximum nausea score was lower in the combination group only at $72 \mathrm{hr}$ after surgery (Table 2). Although there was a numerically lower occurrence of nausea, vomiting, and use of rescue antiemetic in the combination group, the difference did not reach statistical significance (Table 3).

There were no differences in sedation scores, incidence of drowsiness, postdischarge activity level, and satisfaction with PONV management. No episode of oversedation was noted. There were no serious adverse events noted in any of the study subjects.

\section{Discussion}

This study shows that from 24 to $72 \mathrm{hr}$ following surgery the combination of granisetron and promethazine achieved a greater total response rate than promethazine alone. From 6 to $72 \mathrm{hr}$ after surgery, the severity of nausea in the combination group was also lower than in the promethazine group. However, there was no statistical difference between the combination and the granisetron group.

Current standard of care does not recommend the routine administration of antiemetic prophylaxis beyond discharge following ambulatory surgery in high-risk patients. In this study, we tested whether continued administration of low-dose granisetron and promethazine beyond discharge would reduce the incidence of PDNV compared with individual antiemetics. The combination group achieved a higher efficacy rate only when compared with promethazine alone.

Previous studies examining the use of antiemetic prophylaxis beyond discharge in high-risk patients have demonstrated increased efficacy when compared with placebo. In a placebo-controlled trial, Gan et al. ${ }^{13}$ found that continued administration of ondansetron orally disintegrating tablets (ODT) beyond discharge from an ambulatory surgery center resulted in a significant reduction of PDNV in patients undergoing ambulatory laparoscopic cholecystectomies in day surgery. A recent study in pediatric patients undergoing tonsillectomy or adenoidectomy in an ambulatory setting also reported a lower incidence of PDNV when given five doses of ondansetron ODT over 3 days. ${ }^{14}$ Other studies have compared granisetron with other serotonin antagonists for preventing PDNV. White et al. ${ }^{15}$ compared ondansetron $4 \mathrm{mg} i v$ at the end of the surgery versus granisetron $1 \mathrm{mg}$ po administered prior to induction of anesthesia. They found equal efficacy between the two treatment groups up to $48 \mathrm{hr}$ after surgery. In laparoscopic cholecystectomy 
Fig. 1 Patient disposition

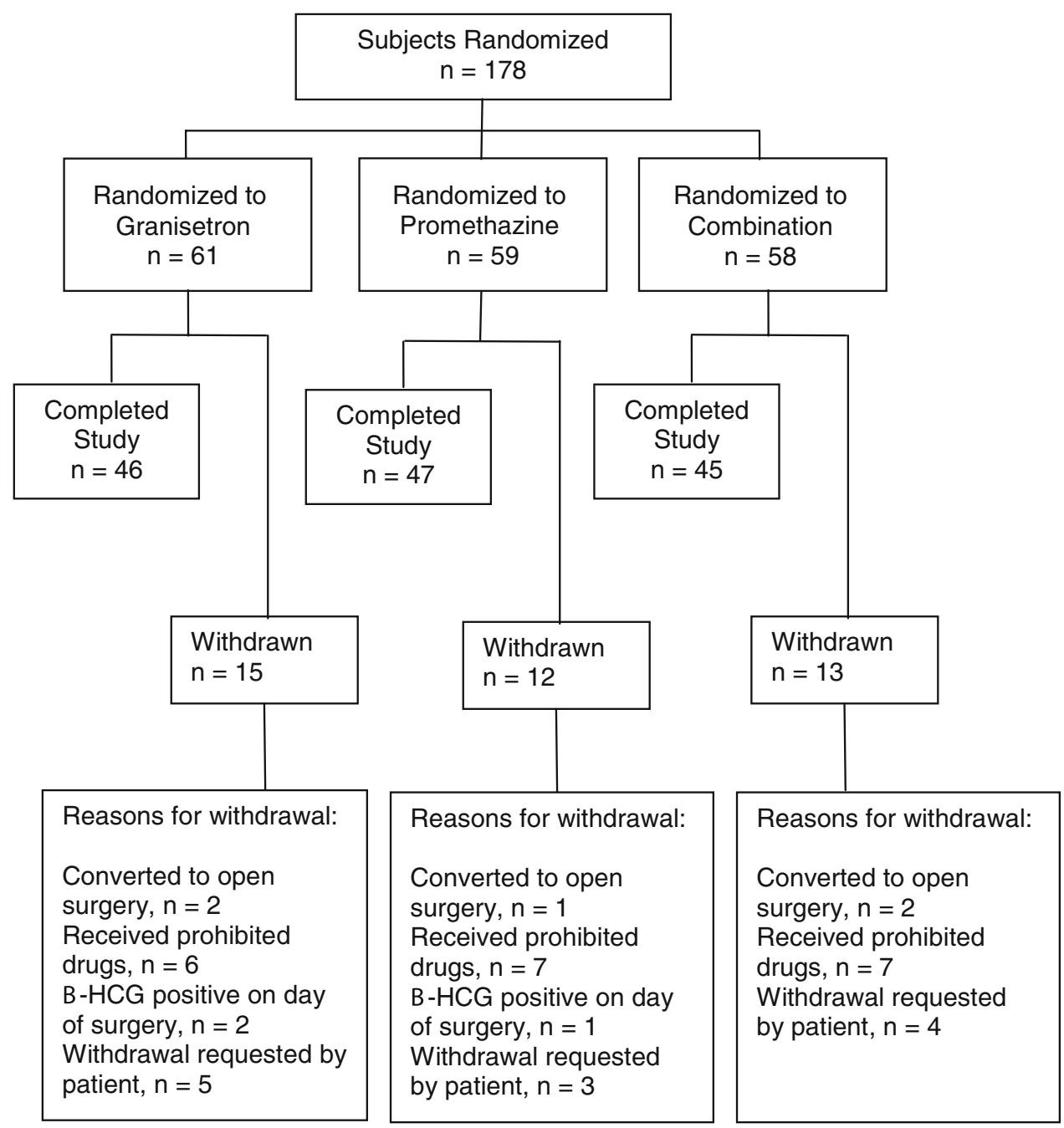

Table 1 Patient demographics

\begin{tabular}{llll}
\hline & Granisetron $(n=46)$ & Promethazine $(n=47)$ & Combination $(n=45)$ \\
\hline Age & $34.3 \pm 8.3$ & $33 \pm 6.5$ & $32.8 \pm 7.2$ \\
Weight $(\mathrm{kg})$ & $79.5 \pm 25.3$ & $77.0 \pm 19.6$ & $80.5 \pm 23.0$ \\
Height $(\mathrm{cm})$ & $164.3 \pm 6.6$ & $161.6 \pm 18.2$ & $164.9 \pm 6.9$ \\
ASA physical status & & & 29 \\
I & 32 & 30 & 62 \\
II & 57 & 63 & 9 \\
III & 11 & 7 & $107.3 \pm 50.0$ \\
Duration of anesthesia (min) & $109.6 \pm 54.2$ & $106.2 \pm 62.5$ & $42 \pm 50$ \\
Postoperative fentanyl $(\mu \mathrm{g})$ & $58 \pm 73$ & $37.2 \pm 46$ & 8.1 \\
Smoker & 17.5 & 20.5 & 27.0 \\
History of PONV & 22.5 & 20.5 & 21.6 \\
History of motion sickness & 32.5 & 35.9 & $4.6 \pm 0.5$ \\
Sedation score at PACU discharge & $4.7 \pm 0.5$ & $4.4 \pm 0.7$ &
\end{tabular}

Number in $\%$ or mean $\pm \mathrm{SD}$

ASA American Society of Anesthesiologists; PONV postoperative nausea and vomiting; PACU postanesthesia care unit 
Fig. 2 The cumulative incidence of total response rate and $95 \%$ confidence limits (no vomiting, no more than mild nausea, and no antiemetic rescue). * For combination group versus promethazine: $P<0.013$ at $6 \mathrm{hr}, P=0.008$ at $24 \mathrm{hr}, P=0.004$ at $48 \mathrm{hr}$, and $P=0.004$ at $72 \mathrm{hr}(P$ values adjusted for all time $\times$ group comparisons)

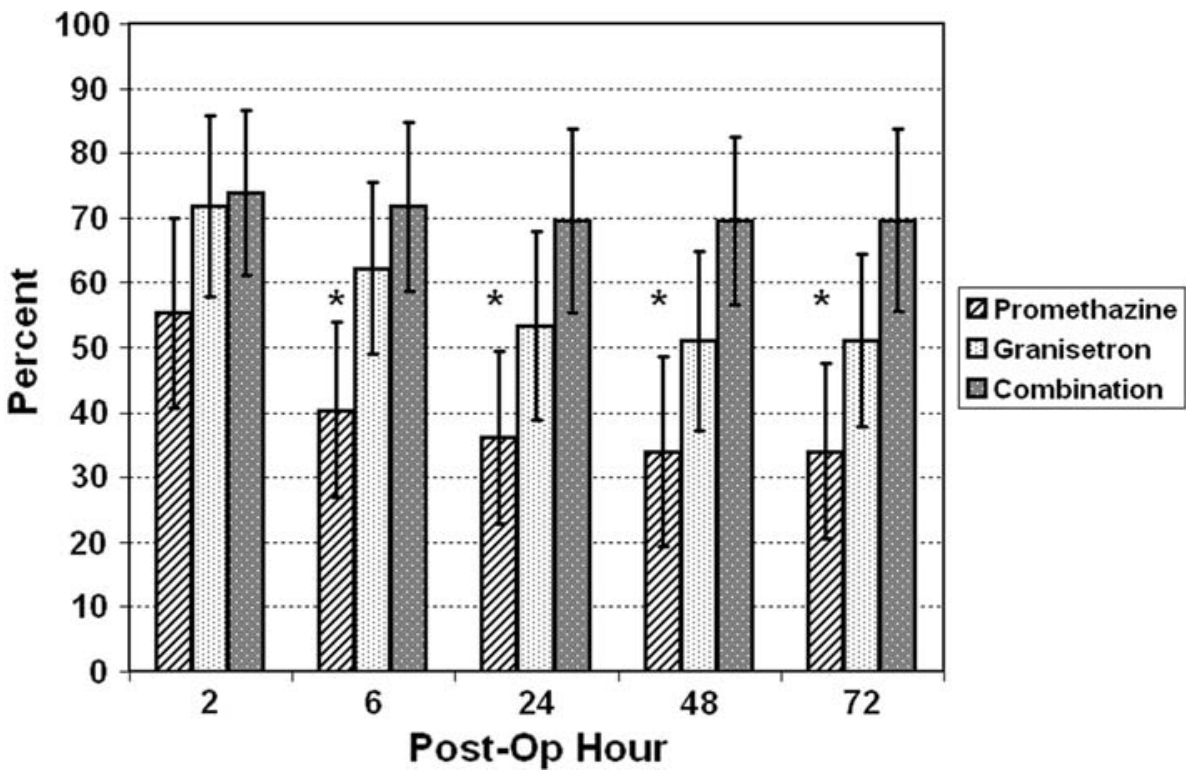

Table 2 Maximum nausea scores

\begin{tabular}{lllll}
\hline & Granisetron $(n=46)$ & Promethazine $(n=47)$ & Combination $(n=45)$ & $P$ value overall (versus combination) \\
\hline $2 \mathrm{hr}$ & $1.6 \pm 2.7$ & $2.6 \pm 3.4$ & $1.1 \pm 2.0$ & 0.17 \\
& $0(0-2)$ & $0(0-5)$ & $0(0-2)$ & $0.041(0.0044)$ \\
$6 \mathrm{hr}$ & $2.5 \pm 3.2$ & $3.7 \pm 3.6^{*}$ & $1.5 \pm 2.1$ & $0.024(0.0025)$ \\
& $0.5(0-4)$ & $3(0-8)$ & $0(0-3)$ & $0.0076(0.0008)$ \\
$24 \mathrm{hr}$ & $3.1 \pm 3.2$ & $4.0 \pm 3.6^{*}$ & $1.7 \pm 2.2$ & $0.0060(0.028,0.0006)$ \\
& $3(0-5)$ & $5(0-8)$ & $1.7 \pm 2.2$ & $0(0-3)$ \\
$78 \mathrm{hr}$ & $3.4 \pm 3.4$ & $4.3 \pm 3.5^{*}$ & $1.7 \pm 2.2$ & $0(0-3)$ \\
\end{tabular}

Data presented as mean \pm SD and median (25-75\%)

$* P<0.01$ pairwise comparisons between combination group versus promethazine group

** $P=0.028$ between combination group versus granisetron group. $P$ values reflect Kruskall-Wallis test of difference between treatment groups adjusted by the step-down permutation method

patients, Erhan et al. ${ }^{16}$ compared intravenous ondansetron $4 \mathrm{mg}$, granisetron $3 \mathrm{mg}$, or dexamethasone $8 \mathrm{mg}$ with placebo. All active treatment groups were more effective than placebo. However, there is a paucity of data in the literature comparing combination antiemetic therapy with single antiemetic therapy for the prevention of PDNV.

The recent consensus panel guidelines of the Society of Ambulatory Anesthesia (SAMBA) recommend that combination antiemetic therapy be used in high-risk subjects. ${ }^{4}$ Several previous studies have demonstrated that combination antiemetics were superior to individual drugs for the prophylactic prevention of PONV. ${ }^{17-21}$ The results from this study are consistent with the previous findings. Johns et al. demonstrated that the use of granisetron $1 \mathrm{mg} i v$ and cyclizine $50 \mathrm{mg} i v$ was associated with a higher efficacy compared with an individual antiemetic in patients undergoing ambulatory surgery. However, there was a high incidence of dizziness (40\%) and drowsiness (55-56\%) in the cyclizine and the combination groups. This may have been related to the higher dose of cyclizine used. The study was also limited to a 24-h collection of postoperative data, and the anesthetic regimen was not standardized. ${ }^{19}$

The dosing of antiemetics used in this study was lower than previous studies. Granisetron $0.35 \mathrm{mg} i v$ has been demonstrated to provide good antiemetic coverage. A recent study found that granisetron $0.1 \mathrm{mg}$ achieved similar efficacy with ondansetron $4 \mathrm{mg} i v$ when both drugs were used in combination with dexamethasone $8 \mathrm{mg} .^{22}$ Promethazine has been demonstrated to be associated with significant sedative effects when used in higher doses, especially when an opioid is used in conjunction. A recent study found promethazine $6.25 \mathrm{mg}$ iv to have similar 
Table 3 Incidence of nausea, vomiting, and use of rescue antiemetic

\begin{tabular}{|c|c|c|c|}
\hline$N(\%)$ & $\begin{array}{l}\text { Granisetron } \\
(n=46)\end{array}$ & $\begin{array}{l}\text { Promethazine } \\
(n=47)\end{array}$ & $\begin{array}{l}\text { Combination } \\
(n=45)\end{array}$ \\
\hline \multicolumn{4}{|c|}{ Nausea } \\
\hline $2 \mathrm{hr}$ & 17 (37) & $23(49)$ & $14(31)$ \\
\hline $6 \mathrm{hr}$ & $12(26)$ & $16(34)$ & $6(13)$ \\
\hline $24 \mathrm{hr}$ & $12(26)$ & $12(26)$ & $8(18)$ \\
\hline $48 \mathrm{hr}$ & 8 (17) & 9 (19) & $4(9)$ \\
\hline $72 \mathrm{hr}$ & $9(20)$ & $5(11)$ & $1(2)$ \\
\hline \multicolumn{4}{|c|}{ Vomiting } \\
\hline $2 \mathrm{hr}$ & $5(11)$ & $6(13)$ & $4(9)$ \\
\hline $6 \mathrm{hr}$ & $5(11)$ & $3(6)$ & $1(2)$ \\
\hline $24 \mathrm{hr}$ & $2(4)$ & $2(4)$ & 0 \\
\hline $48 \mathrm{hr}$ & $2(4)$ & $1(2)$ & 0 \\
\hline $72 \mathrm{hr}$ & 0 & $2(4)$ & 0 \\
\hline \multicolumn{4}{|c|}{ Rescue } \\
\hline $2 \mathrm{hr}$ & $10(22)$ & 17 (36) & $9(20)$ \\
\hline $6 \mathrm{hr}$ & $1(2)$ & $3(7)$ & 0 \\
\hline $24 \mathrm{hr}$ & 0 & $2(4)$ & 0 \\
\hline $48 \mathrm{hr}$ & 0 & $1(2)$ & $1(2)$ \\
\hline $72 \mathrm{hr}$ & 0 & 0 & 0 \\
\hline
\end{tabular}

Data presented as number of patients (percentages)

efficacy to ondansetron $4 \mathrm{mg} i v$ when used as a rescue antiemetic, with no difference in the duration of PACU stay. ${ }^{8}$ The current study shows superior efficacy when granisetron is combined with promethazine in these low doses. We also demonstrated that administration of antiemetics beyond discharge was associated with a low incidence of PDNV. Prophylactic antiemetics may be administered either at induction of anesthesia or toward the end of surgery. As demonstrated in previous studies, we administered the antiemetics toward the end of surgery to maximize their efficacy as most antiemetics are relatively short acting. ${ }^{4,23}$

There are limitations to this study. The conclusion is only valid relative to the doses used in this trial. The original design included a placebo group. However, as the patients studied were at high risk for developing PONV, it was the view of the institutional review boards at both centers that it would not be ethical to include a placebo group as it would deviate from the standards of care. The other limitation is the recruitment of only women; hence the results may not be widely applicable to men or patients undergoing other procedures. Since they have a threefold increase in their risk of developing PONV compared with men, a study of women is clearly appropriate to address this problem. It could be argued that inhalational anesthetic should not be used for maintenance of anesthesia given the patients are high risk for developing PONV. However, at least in the US, inhalational-based anesthetic remains widely used, more so than propofol-based anesthetic. Finally, there was a trend in the data demonstrating superior efficacy in the combination group when compared with the granisetron group. However, due to the lower than expected incidence of nausea and vomiting in the granisetron group, statistical significance was not shown consistently throughout the study. Therefore, a definitive conclusion demonstrating superior efficacy of the combination over granisetron alone cannot be reached and a larger study will need to be conducted.

In summary, in patients undergoing ambulatory gynecological laparoscopy, the combination of low-dose granisetron and promethazine was more effective than promethazine alone in reducing the incidence of PONV and PDNV without untoward side effects. The combination was also more effective than promethazine alone in reducing the severity of nausea.

Acknowledgments We would like to thank Adam Buntaine, BS, Cristina Francois, BS, Nilda Itchon Ramos, MD, Greys Sanchez, MD, and Erlinda Yeh, MD for their efforts in conducting this study. This study was sponsored by Roche, Inc.

Competing interests None declared.

\section{References}

1. Habib AS, Chen YT, Taguchi A, Hu XH, Gan TJ. Postoperative nausea and vomiting following inpatient surgeries in a teaching hospital: a retrospective database analysis. Curr Med Res Opin 2006; 22: 1093-9.

2. Carroll NV, Miederhoff P, Cox FM, Hirsch JD. Postoperative nausea and vomiting after discharge from outpatient surgery centers. Anesth Analg 1995; 80: 903-9.

3. White PF, O'Hara JF, Roberson CR, Wender RH, Candiotti KA, POST-OP Study Group. The impact of current antiemetic practices on patient outcomes: a prospective study on high-risk patients. Anesth Analg 2008; 107: 452-8.

4. Gan TJ, Meyer TA, Apfel CC, et al. Society for Ambulatory Anesthesia guidelines for the management of postoperative nausea and vomiting. Anesth Analg 2007; 105: 1615-28.

5. Wilson AJ, Diemunsch $P$, Lindeque $B G$, et al. Single-dose i.v. granisetron in the prevention of postoperative nausea and vomiting. Br J Anaesth 1996; 76: 515-8.

6. D'Angelo R, Philip B, Gan TJ, et al. A randomized, double-blind, close-ranging, pilot study of intravenous granisetron in the prevention of postoperative nausea and vomiting in patients abdominal hysterectomy. Euro J Anaesthesiol 2005; 22: 774-9.

7. Gan TJ. Mechanisms underlying postoperative nausea and vomiting and neurotransmitter receptor antagonist-based pharmacotherapy. CNS Drugs 2007; 21: 813-33.

8. Habib AS, Reuveni J, Taguchi A, White WD, Gan TJ. A comparison of ondansetron with promethazine for treating postoperative nausea and vomiting in patients who received prophylaxis with ondansetron: a retrospective database analysis. Anesth Analg 2007; 104: 548-51.

9. Khalil S, Philbrook L, Rabb M, et al. Ondansetron/promethazine combination or promethazine alone reduces nausea and vomiting after middle ear surgery. J Clin Anesth 1999; 11: 596-600. 
10. Gan TJ, El-Molem H, Ray J, Glass PS. Patient-controlled antiemesis: a randomized, double-blind comparison of two doses of propofol versus placebo. Anesthesiology 1999; 90: 1564-70.

11. Aldrete JA. Modifications to the postanesthesia score for use in ambulatory surgery. J Perianesth Nurs 1998; 13: 148-55.

12. Westfall PH, Tobias RD, Rom D, Wolfinger RD, Hochberg $Y$. Multiple comparisons and multiple tests-using SAS®. Cary, NC: SAS Institute Inc; 1999.

13. Gan TJ, Franiak R, Reeves $J$. Ondansetron orally disintegrating tablet versus placebo for the prevention of postdischarge nausea and vomiting after ambulatory surgery. Anesth Analg 2002; 94: 1199-200.

14. Davis PJ, Fertal KM, Boretsky KR, et al. The effects of oral ondansetron disintegrating tablets for prevention of at-home emesis in pediatric patients after ear-nose-throat surgery. Anesth Analg 2008; 106: 1117-21.

15. White PF, Tang J, Hamza MA, et al. The use of oral granisetron versus intravenous ondansetron for antiemetic prophylaxis in patients undergoing laparoscopic surgery: the effect on emetic symptoms and quality of recovery. Anesth Analg 2006; 102: 1387-93.

16. Erhan $Y$, Erhan E, Aydede H, Yumus O, Yentur A. Ondansetron, granisetron, and dexamethasone compared for the prevention of postoperative nausea and vomiting in patients undergoing laparoscopic cholecystectomy: a randomized placebo-controlled study. Surg Endosc 2008; 22: 1487-92.

17. Pueyo FJ, Lopez-Olaondo L, Sanchez-Ledesma MJ, Ortega A, Carrascosa $F$. Cost-effectiveness of three combinations of antiemetics in the prevention of postoperative nausea and vomiting. Br J Anaesth 2003; 91: 589-92.

18. Biswas BN, Rudra A. Comparison of granisetron and granisetron plus dexamethasone for the prevention of postoperative nausea and vomiting after laparoscopic cholecystectomy. Acta Anaesthesiol Scand 2003; 47: 79-83.

19. Johns RA, Hanousek J, Montgomery JE. A comparison of cyclizine and granisetron alone and in combination for the prevention of postoperative nausea and vomiting. Anaesthesia 2006; 61: 1053-7.

20. Maddali MM, Mathew J, Fahr J, Zarroug AW. Postoperative nausea and vomiting in diagnostic gynaecological laparoscopic procedures: comparison of the efficacy of the combination of dexamethasone and metoclopramide with that of dexamethasone and ondansetron. J Postgrad Med 2003; 49: 302-6.

21. Fujii $Y$, Tanaka $H$. Granisetron versus granisetron/dexamethasone combination for the treatment of nausea, retching, and vomiting after major gynecologic surgery: a randomized, double-blind study. Clin Ther 2003; 25: 507-14.

22. Gan TJ, Coop A, Philip BK. A randomized, double-blind study of granisetron plus dexamethasone versus ondansetron plus dexamethasone to prevent postoperative nausea and vomiting in patients undergoing abdominal hysterectomy. Anesth Analg 2005; 101: 1323-9.

23. Sun $R$, Klein $K W$, White $P F$. The effect of timing of ondansetron administration in outpatients undergoing otolaryngologic surgery. Anesth Analg 1997; 84: 331-6. 